The 9th International Symposium on Automation and Robotics in Construction June 3-5, 1992 Tokyo, Japan

\title{
TOTAL SHIELD CONSTRUCTION CONTROL SYSTEM
}

\author{
Kenichi Takemura \\ Tsutomu Nemoto \\ Kajima Corporation \\ Mechanical Engineering Development Section \\ Machinery \& Equipment Department \\ Construction Group \\ Kajima Corporation \\ 2-7, Motoakasaka 1-chome \\ Minato-ku,Tokyo,Japan 107
}

\begin{abstract}
We have connected the various automatic construction systems for shield construction by a high speed network. We have developed a "Total Shield Construction Control System" (KSGS Kajima Shield General Control System) that controls all the systems in a centralized control room. This control system has already been installed on site. The features of this system are reported here.
\end{abstract}

\section{Introduction}

The total shield construction control system (KSGS) integrates the "Excavation Control System," the "Automatic Surveying System," the "Automatic Direction Control System," and the "Fluid Transport Instrumentation System" in the total shield construction control room installed outside the underground space. The shield instruments are remote controlled.

In addition to elimination of labor, safe and efficientconstruction in shield work, automatic systems for individual construction units and development of element technology have almost reached the saturation stage. The key to full automation and realization of fully unmanned operations, however, lies in the efficient integration and unified control of each of these

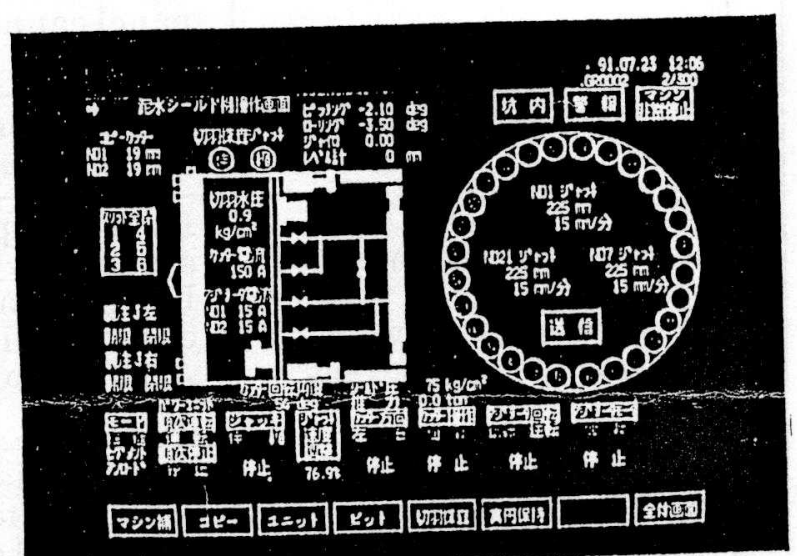

Photograph 1. Shield Machine individual automatic systems.

Kajima Corporation has already developed an excavation control system for controlling the operating conditions of the shield machine and an automatic measuring system for controlling the position and posture of the shield machine. The KSGS developed this time, integrates these individual construction control systems and enables centralized control of the shield construction conditions at one location.

The advantage of KSGS is that it can be easily used in any site. Therefore, instruments can be standardized. Furthermore, by linking the underground space, the total shield construction control room and the plants byspace, the total shield construction control room and the plants by a high speed network, the control data of each equipment can be sent from the total shield construction control room to the shield machine and the plant. 
The equipment can be automatically controlled and data can be saved. Daily reports can be automatically prepared. From the touch panel on the screen of the operator space, the total shield construction control room and the plants by a high speed network, the control data of each equipment can be sent from the total shield construction control room to the shield machine and the plant. display station in the total shield construction control room, the operator of the shield machine can operate and monitor the shield machine and the plant by remote control. Also, the monitoring of data of temperature, humidity, oxygen

concentration, visitor control system and materials control system can be integrated.

The KSGS is currently in the fully operating state in Osaka Area A, Osaka Area B, and Nagoya Area. In addition, it is scheduled for installation at other locations also.

II. Outline of the System

1. Table 1 shows the status, problems and ideal conditions, up to the development of KSGS.

Table 1. Status, Problems and Ideal Conditions

\begin{tabular}{|c|c|c|c|}
\hline & Status & Problems & Ideal Conditions \\
\hline 1 & - Several operation panels & $\begin{array}{l}\text { - One-man operation is } \\
\text { difficult. } \\
\text { - The shield machine operation } \\
\text { panel cannot be used for other } \\
\text { purposes }\end{array}$ & $\begin{array}{l}\text {. Centralized operations of } \\
\text { all equipment in the } \\
\text { control room } \\
\text { Fully automatic }\end{array}$ \\
\hline 2 & - Several meter panels & $\begin{array}{l}\text { Data dispersed in various } \\
\text { meter panels and displays }\end{array}$ & - Centralization of data \\
\hline 3 & $\begin{array}{l}\text { Several personal } \\
\text { computers, displays and } \\
\text { printers } \\
\text {. Several systems with } \\
\text { independent functions }\end{array}$ & $\begin{array}{l}\text { Data is dispersed in each } \\
\text { system. } \\
\text { Integration and unification of } \\
\text { data is difficult. } \\
\text { Aesthetic appearance is not } \\
\text { good. }\end{array}$ & $\begin{array}{l}\text { Integration and } \\
\text { unification of data }\end{array}$ \\
\hline 4 & $\begin{array}{l}\text { Signal transmission } \\
\text { system (several } \\
\text { transmission lines and } \\
\text { transmission equipment) }\end{array}$ & $\begin{array}{l}\text { - Construction and } \\
\text { maintenance are complicated. } \\
\text {. Large load on the signal I/O } \\
\text { unit software. }\end{array}$ & $\begin{array}{l}\text { Simple signal } \\
\text { transmission system }\end{array}$ \\
\hline
\end{tabular}

2. Considerations in the Construction of the System

Table 2 shows the considerations in the construction of the system.

Table 2. Considerations in the construction of the system

\begin{tabular}{|c|l|l|}
\hline & \multicolumn{1}{|c|}{ Ideal Conditions } & \multicolumn{1}{c|}{ Considerations } \\
\hline 1 & $\begin{array}{l}\text { One-man operation of all equipment in the } \\
\text { control room }\end{array}$ & One operation panel \\
\hline 2 & Centralization of data & Few selector type displays \\
\hline 3 & Integration and unification of data & Few multitasking computers \\
\hline
\end{tabular}


Table 2. Considerations in the construction of the system (cont'd)

\begin{tabular}{|c|l|c|}
\hline & \multicolumn{1}{|c|}{ Ideal Conditions } & \multicolumn{1}{c|}{ Considerations } \\
\hline 4 & $\begin{array}{l}\text { Simple signal transmission system (transmission } \\
\text { equipment and transmission line) }\end{array}$ & Common bus or LAN \\
\hline \multirow{4}{*}{ Others } & $\begin{array}{l}\text { a) Generality, operability and convertibility have been particularly considered } \\
\text { with the prerequisite of usage in various sites. }\end{array}$ \\
& $\begin{array}{l}\text { Individual control system capable of addition and expansion } \\
\text { c) } \begin{array}{l}\text { Arrange the operation room for FA and plant in a similar way and erase the } \\
\text { dreate Kajima's own system capable of automatic direction control and } \\
\text { automatic excavating operation }\end{array}\end{array}$ \\
\hline
\end{tabular}

3. Development period

Development start November 1990 - Operation start

September 1991 Osaka Area B

November 1991 Osaka Area A

February 1992 Nagoya Area

4. Outline of system

(1) System configuration

Fig. 1 shows the system configuration.

Fig. 1 System Configuration

Total Shield Construction Control Room

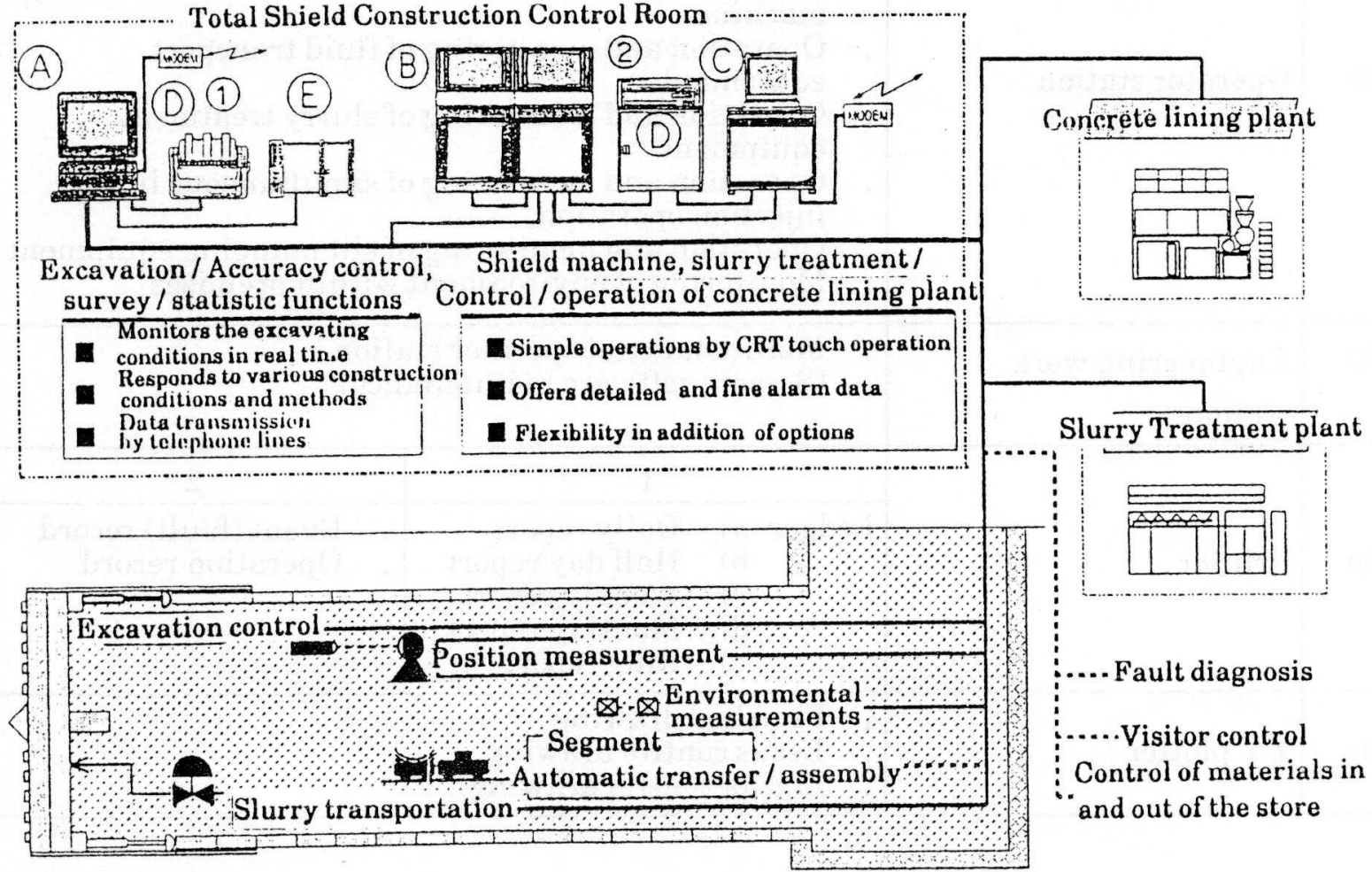


(2) Functions of each device (total shield construction control room)

Fig. 1 shows the functions of devices in the total shield construction control room.

Table 3 Functions of each device (total shield construction control room)

\begin{tabular}{|c|c|c|c|c|c|}
\hline & Name of Device & \multicolumn{4}{|c|}{ Function } \\
\hline $\mathrm{A}$ & Line computer & \multicolumn{4}{|c|}{ 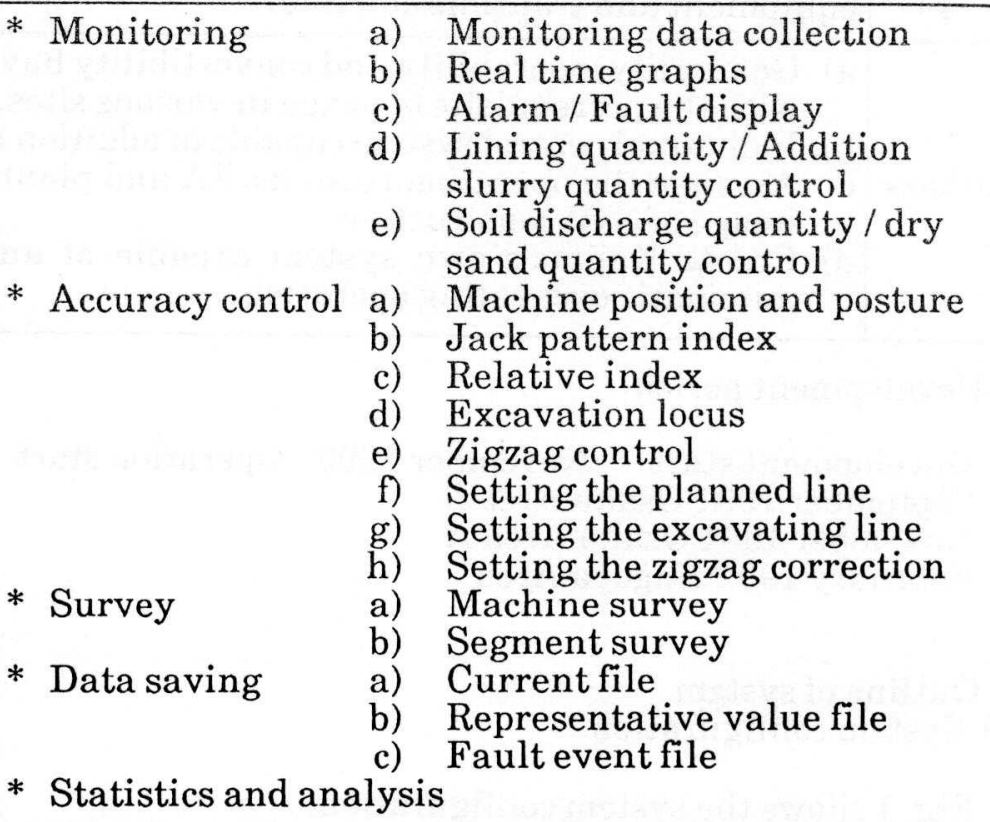 } \\
\hline B & Operator station & \multicolumn{4}{|c|}{$\begin{array}{l}\text { Excavation operation of shield excavating machine } \\
\text { - Monitoring and posture display of shield excavating } \\
\text { machine } \\
\text { - Operation and monitoring of fluid transport } \\
\text { equipment } \\
\text { - Operation and monitoring of slurry treatment } \\
\text { equipment } \\
\text { Operation and monitoring of simultaneous lining } \\
\text { injection operation } \\
\text { - Operation and monitoring of silt pumping equipment } \\
\text { Monitoring of environment within premises }\end{array}$} \\
\hline $\mathrm{C}$ & $\begin{array}{l}\text { Engineering work } \\
\text { station }\end{array}$ & \multicolumn{4}{|c|}{$\begin{array}{ll}\text { Maintenance of operator station } \\
\text { (Screen, software maintenance) }\end{array}$} \\
\hline & & \multicolumn{3}{|c|}{1} & 2 \\
\hline $\mathrm{D}$ & Printer & \multicolumn{3}{|c|}{$\begin{array}{cl}\text { Ledger a) } & \text { Daily report } \\
\text { b) } & \text { Half day report } \\
\text { c) } & \text { Weekly report } \\
\text { d) } & \text { Monthly report } \\
\text { e) } & \text { Ring report }\end{array}$} & $\begin{array}{l}\text { Event (fault) record } \\
\text { - } \quad \text { Operation record }\end{array}$ \\
\hline $\mathrm{E}$ & XY plotter & \multicolumn{4}{|c|}{$\begin{array}{l}\text { Finished drawing } \\
\text { - Locus control drawing } \\
\text { Zigzag control drawing }\end{array}$} \\
\hline
\end{tabular}

* The symbols correspond to the symbols shown in the System Configuration Diagram of Fig. 1 


\section{System Control and Control Description}

Table 4 shows the KSGS controls and control description.

Table 4 KSGS Control and Control Description

\begin{tabular}{|c|c|c|}
\hline 1 & Excavation control & $\begin{array}{l}\text { Displays the operating status of shield machine, slurry } \\
\text { injection??? status, concrete lining status, slurry } \\
\text { transportation and plant operating conditions on the } \\
\text { screen. Automatically registers the data during the } \\
\text { excavating operation and saves the data in the hard } \\
\text { disk. }\end{array}$ \\
\hline 2 & $\begin{array}{l}\text { Automatic daily report } \\
\text { preparation }\end{array}$ & $\begin{array}{l}\text { Aisk. } \\
\text { various type of controls and equipment operation data. }\end{array}$ \\
\hline 3 & $\begin{array}{l}\text { Monitoring of shield } \\
\text { machine operation }\end{array}$ & $\begin{array}{l}\text { Displays the operating status of the shield machine so } \\
\text { that it can be easily read. Reports faults by alarms. } \\
\text { Enables remote operation by touch operation of the } \\
\text { display. }\end{array}$ \\
\hline 4 & $\begin{array}{l}\text { Monitoring of plant } \\
\text { operation }\end{array}$ & $\begin{array}{l}\text { Displays the plant operating status such as slurry } \\
\text { injection???, concrete lining, slurry transportation. } \\
\text { Reports faults by alarms. Enables remote operation of } \\
\text { the plant and various pumps by touch operation of the } \\
\text { display. }\end{array}$ \\
\hline 5 & $\begin{array}{l}\text { Monitoring of the } \\
\text { underground } \\
\text { environment }\end{array}$ & $\begin{array}{l}\text { Retrieves data of temperature, humidity, oxygen } \\
\text { concentration and combustible gases from the sensors } \\
\text { and displays the data on the screen. Reports faults by } \\
\text { alarms. Automatically records and saves the data. }\end{array}$ \\
\hline 6 & $\begin{array}{l}\text { Monitoring of alarms and } \\
\text { faults }\end{array}$ & $\begin{array}{l}\text { Displays the faults and abnormalities in the shield } \\
\text { machine, various plants and environment within the } \\
\text { premises. Outputs alarms simultaneously. }\end{array}$ \\
\hline 7 & $\begin{array}{l}\text { Shield machine } \\
\text { automatic survey }\end{array}$ & $\begin{array}{l}\text { Measures the position and posture of the shield machine } \\
\text { in real time by using the total station installed in the } \\
\text { shield machine Displays the measured data, } \\
\text { displacement from the basic line and heading of the } \\
\text { shield machine. }\end{array}$ \\
\hline 8 & Link bus & $\begin{array}{l}\text { Links the shield machine control panel, the total shield } \\
\text { construction control room and the plant. Transmits data } \\
\text { at high speed. }\end{array}$ \\
\hline 9 & $\begin{array}{l}\text { Automatic direction } \\
\text { control }\end{array}$ & $\begin{array}{l}\text { Calculates the excavating direction from the data of the } \\
\text { automatic survey instrument, gyro compass and } \\
\text { inclinometer. Automatically controls the direction of } \\
\text { the shield machine. }\end{array}$ \\
\hline 10 & Others & $\begin{array}{l}\text { Various types of independent units of equipment can be } \\
\text { used as options. }\end{array}$ \\
\hline
\end{tabular}




\section{Functional Configuration of System}

See Fig. 2 for functional configuration of KSGS

\section{Examples of Installations}

1. Locations where system is installed with control and monitoring items.

Fig. 3 shows the locations where the system is installed with control and monitoring items.

Fig. 3 KSGS Installation Locations, Control and Monitoring Items

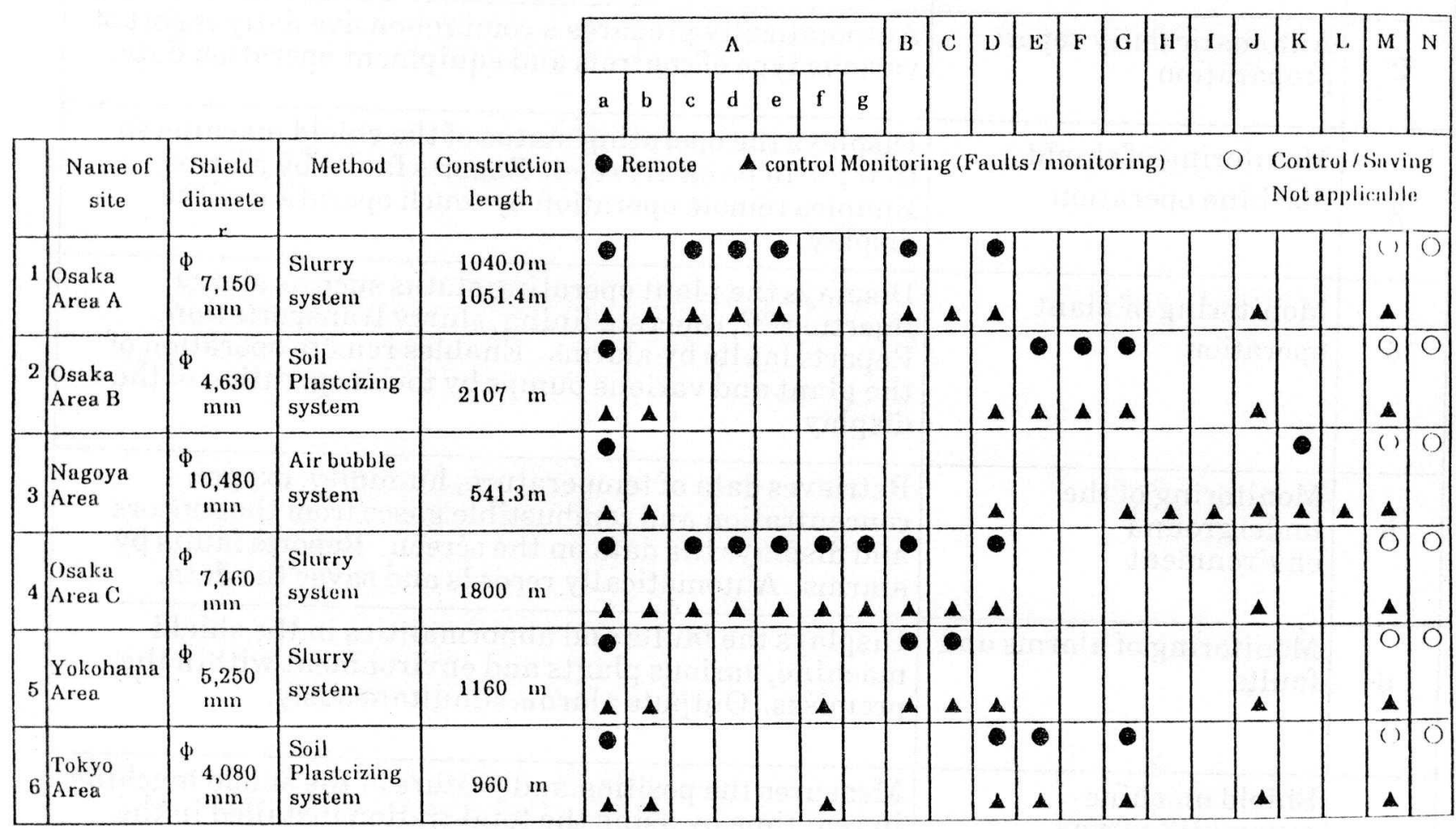

\begin{tabular}{|c|c|l|}
\hline a & Shield machine \\
\hline b & Posture and position measurements \\
\hline a & Slit opening / closing \\
\cline { 2 - 3 } d & Face settlement exploration \\
\hline e & Roundness retaining equipment \\
\hline $\mathrm{f}$ & Special shield machine \\
\hline $\mathrm{g}$ & 'Tail sealer \\
\hline B & Fluid transportation equipment \\
\hline C & Primary processing equipment \\
\hline D & Concrete lining injection equipment \\
\hline
\end{tabular}

\begin{tabular}{|c|l|}
\hline $\mathrm{E}$ & Silt pumping equipment \\
\hline $\mathrm{F}$ & Silt refining equipment \\
\hline $\mathrm{G}$ & Slurry addition equipment \\
\hline $\mathrm{H}$ & Air bubble injection equipment \\
\hline $\mathrm{I}$ & Soil discharge weight measurement \\
\hline $\mathrm{J}$ & Failure measuremen \\
\hline $\mathrm{K}$ & Automatic direction control \\
\hline $\mathrm{L}$ & Automatic survey \\
\hline $\mathrm{M}$ & Excavation control \\
\hline $\mathrm{N}$ & Automatic daily report preparation \\
\hline
\end{tabular}


IV. Results of Introducing the System

\section{Results of introducing KSGS}

The results of introducing the KSGS system are:

(1) High accuracy in excavating operations is obtained.

The current position of the shield machine and its deviation from the planned line can be calculated and displayed in real time by input of data of the planned excavating line in the line computer. Therefore, high accuracy in the excavating operation is attained.

(2) Stable excavating operation is enabled.

The excavation data of the shield machine is calculated and processed in the line computer, and displayed in the form of graphs. Therefore, the excavating status can be accurately extracted.Also, by setting the control limits beforehand, if there is a deviation from the control value, the display color changes. Simultaneously an alarm is output to notify the operator.

(3) Labor is eliminated because of centralized operations.

he operations of shield machine, fluid transport equipment and other equipment can be remote controlled without using the above-ground operation panel. This remote control operation is by using the operator station installed in the total shield construction control room.T Simultaneously, the operating status can be monitored.

(4) Data can be centrally controlled.

All the above mentioned operations are performed by one line computer therefore centralized control of data is enabled. Also, daily reports and ledgers can be automatically prepared.

Table 6 . shows the results of introducing the system.

Table 6. Results of Introducing the System

\begin{tabular}{|c|l|l|l|}
\hline & \multicolumn{1}{|c|}{ Result } & \multicolumn{1}{c|}{ Description } \\
\hline 1 & $\begin{array}{l}\text { Operation panel is } \\
\text { simple. }\end{array}$ & $\begin{array}{l}\text { * } \\
\text { The underground shield machine operation panel has been } \\
\text { eliminated. } \\
\text { One-man operation of shield machine and all other types of } \\
\text { plants has become possible. } \\
\text { Manufacture of operation panels for each site is not } \\
\text { necessary. Change over to a different site is possible by } \\
\text { changing the screen. } \\
\text { The shield machine and plant can be operated by touch } \\
\text { operations on the touch panel of the display screen. } \\
\text { Simultaneous real time monitoring is also possible. }\end{array}$ \\
\hline 2 & $\begin{array}{l}\text { Meter panels have } \\
\text { been simplified. }\end{array}$ & $* \begin{array}{l}\text { Meter panels can be displayed by changing over the screen. } \\
\text { Process display and trend graphs can be displayed. }\end{array}$ \\
\hline 3 & $\begin{array}{l}\text { Number of } \\
\text { personal } \\
\text { computers has } \\
\text { decreased. }\end{array}$ & $* \begin{array}{l}\text { The dispersed processing by several PC9801 computers } \\
\text { conventionally, has been replaced by processing by a single } \\
\text { line computer. } \\
\text { All conditions of shield construction can be centrally } \\
\text { controlled using 2 operator stations and one line computer. }\end{array}$ \\
\hline 4 & $\begin{array}{l}\text { Signal } \\
\text { transmission } \\
\text { system has been } \\
\text { simplified. }\end{array}$ & $* \begin{array}{l}\text { The shield machine and various plants can be directly } \\
\text { linked by one link bus. This enables integration and } \\
\text { centralization of data. } \\
\text { Construction and maintenance have become easy. }\end{array}$ \\
\hline
\end{tabular}


Table 6. Results of Introducing the System (cont'd)

\begin{tabular}{|c|c|c|}
\hline & Result & Description \\
\hline \multirow{4}{*}{ Others } & $\begin{array}{l}\text { Equipment can be } \\
\text { easily increased or } \\
\text { decreased. }\end{array}$ & $\begin{array}{l}\text { * The software in the slurry pumping system ??? shield, slurry } \\
\text { shield can be changed and equipment can be added or } \\
\text { removed. } \\
\text { * Various types of independent control systems (visitor } \\
\text { control, underground motion control) for shield construction } \\
\text { can be installed or removed to suit the conditions of the site. } \\
\text { * Equipment can be added and installed easily during the } \\
\text { work. (Addition of fluid transport pump) }\end{array}$ \\
\hline & $\begin{array}{l}\text { Aesthetic } \\
\text { appearance has } \\
\text { improved. }\end{array}$ & $\begin{array}{l}\text { * The appearance is similar to operating rooms for FA and } \\
\text { plant. } \\
\text { * The image of civil construction has been erased. }\end{array}$ \\
\hline & $\begin{array}{l}\text { Kajima's own } \\
\text { automatic } \\
\text { direction control } \\
\text { system has been } \\
\text { realized. }\end{array}$ & $\begin{array}{l}\text { * Equipment has been automated where possible. } \\
\text { * The automatic survey instrument can be connected to } \\
\text { Kajima's own direction control computer.Direction control } \\
\text { of the shield machine is enabled by using fuzzy logic. } \\
\text { * The existing KSGS hardware and software assets have been } \\
\text { diverted. } \\
\text { * The knowhow related to Kajima's own automatic direction } \\
\text { control system has been preserved. }\end{array}$ \\
\hline & \multicolumn{2}{|c|}{$\begin{array}{l}\text { The system is general purpose in nature because of the above mentioned points. } \\
\text { Therefore, it can be developed at various sites. }\end{array}$} \\
\hline
\end{tabular}

Fig. 2 KSGS Functional Configuration Diagram

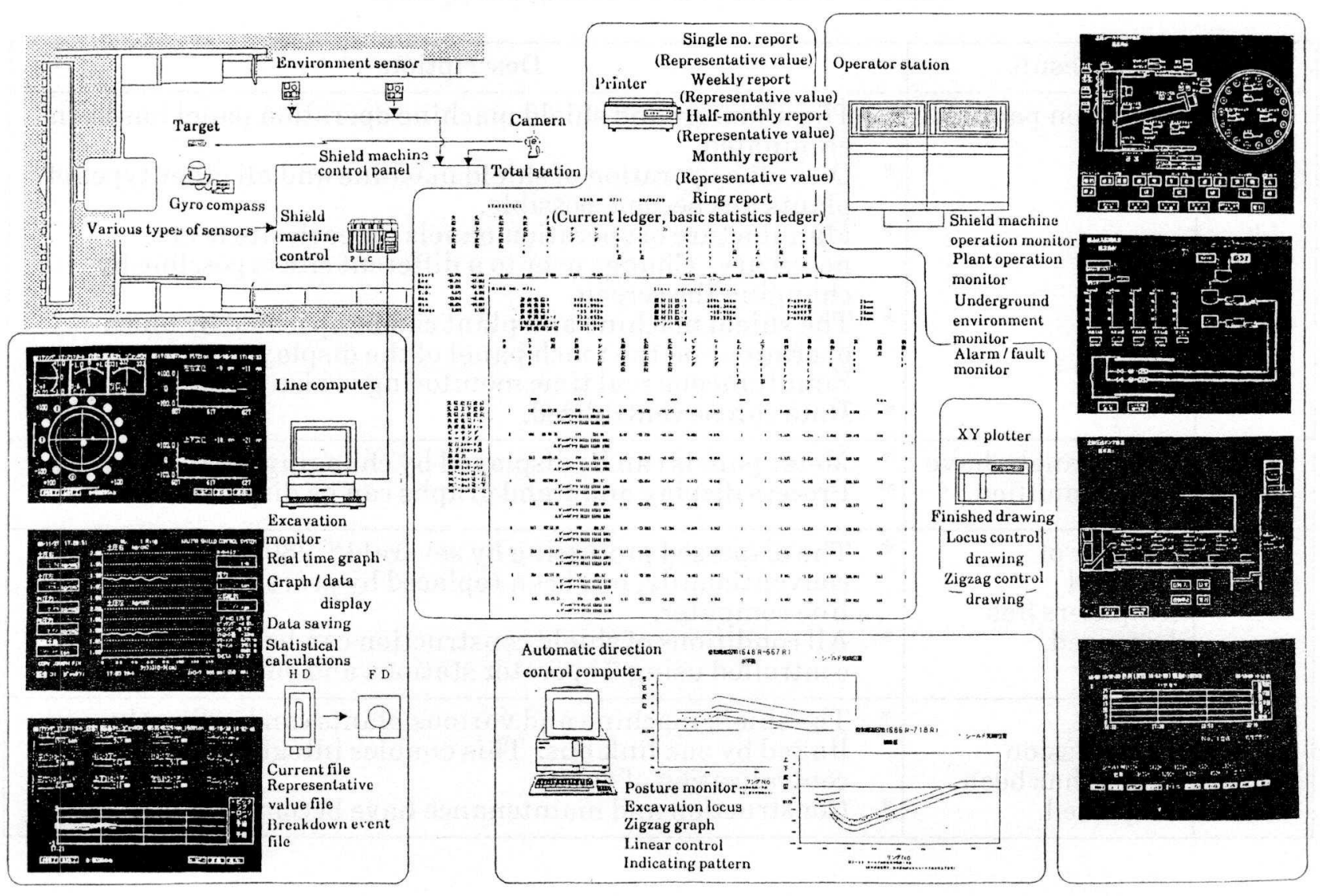




\section{Comparison before and after introducing KSGS}

The control rooms (centralized operation system) before and after introducing KSGS are compared below.

Photograph 2. Centralized Operating Room setore Introducing KSGS

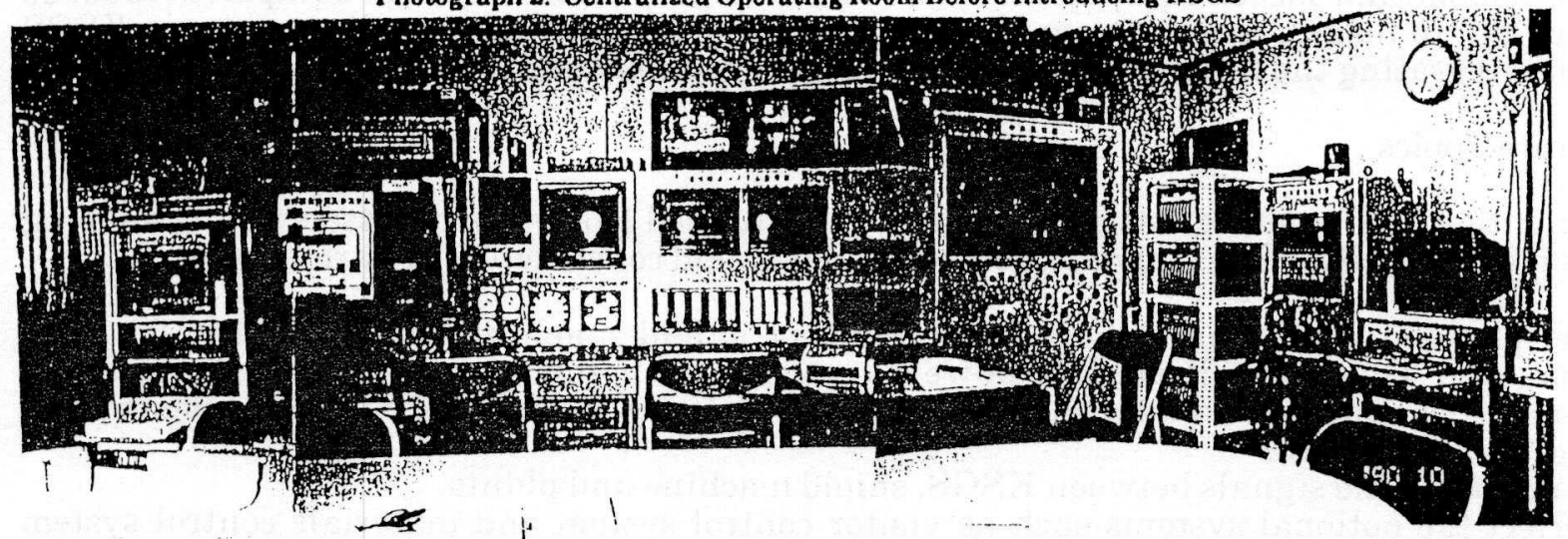

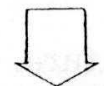

Photograph 3. Total Shield Construction Control Room After Introducing KSGS
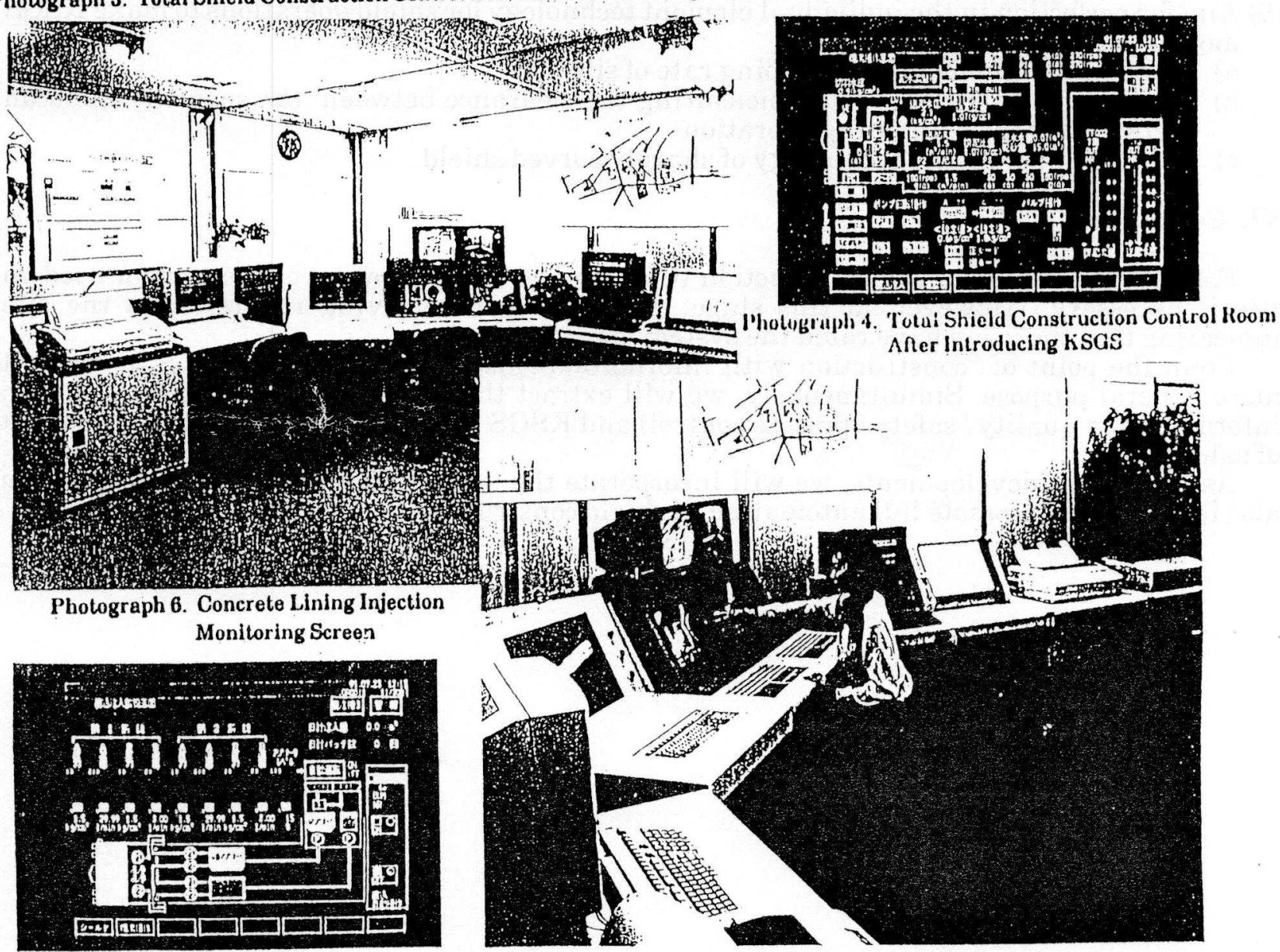


\section{Remaining Problems and Future Topics}

\section{Remaining Problems}

(1) Extracting the status of the face is indispensable for remote control. We have been installing the face at every site now, monitoring ITV at other locations, voice concentration microphone and speech equipment. However, the signal cables for these equipment must be laid out. In future, there is a need for incorporating the ITV and voice line cables in KSGS and integrating the transmission line/ITV/voice equipment in KSGS.

2. Future Topics

Investigation and implementation of the topics mentioned below are necessary for developing and popularizing KSGS as standard equipment for shield construction at various sites.

(1) The planned machines to be used, including shield machines are different for each company. Therefore, time and power are necessary for engineering operations in communications and adjustments of signals. Efficiency in engineering operations will be necessary in future.

(2) Standardize the signals between KSGS, shield machine and plants.

(3) Perfect the optional systems such as visitor control system and materials control system (segments and others).

(4) Make the system more general purpose in nature.

(5) Refine the operating screens of shield machine, plant and others. Perfect the one-man controls and upgrade to a fully automatic shield construction system.

(6) Aim for perfection in the individual element technology for shield operations to make KSGS more sophisticated.

a) Measuring technology for pumping rate of silt.

b) Technology for detecting and measuring the clearance between the segment and scan plate during the excavating operation

c) Automatic surveying technology of sharply curved shield

\section{Conclusion}

For detailed results of the introduction (CR), an overall evaluation of the system used on site is necessary. However, at this stage, we have been receiving reports from the site indicating that the users have rated the system highly.

From the point of "construction with information" also, we will refine KSGS to make it more general purpose. Simultaneously, we will extract the donor's needs (construction with information = quality $/$ safety $/$ process control) and KSGS as a strategic system from the point of sales.

As part of the developments, we will incorporate the automatic segment assembly system also in KSGS and promote full automation in shield construction. 